\title{
FACTORS RELATED TO NEGATIVE STIGMA FOR HIV/ AIDS PATIENTS IN BORO-BORO VILLAGE, RANOMEETO SUB-DISTRICT SOUTH KONAWE REGENCY
}

\author{
Firman $^{1}$, Umi Rachmawati ${ }^{2}$, Wa Ode Pipit ${ }^{3}$ \\ ${ }^{1,2,3}$ College of Health Sciences Mandala Waluya Kendari, Southeast Sulawesi, \\ Indonesia.
}

Corresponding Author: Wa Ode Pipit

Email :waodepipit2@gmail.com

\section{Abstract}

Background: The high number of people living with HIV / AIDS until 2018 has created a negative stigma for HIV / AIDS patients in Boro-Boro Village, Ranomeeto Sub-District, South Konawe Regency. The purpose of this study was to determine the factors associated with negative stigma for HIV / AIDS patients in Boro-Boro Village, Ranomeeto District, South Konawe Regency

Methods: Type of research is quantitative method with a cross-sectional design with a population of 585 people. Sampling technique usedd accidental sampling technique with a sample size of 83 respondents. Analysis data used the chi square test. The independent variable in this study was knowledge about HIV / AIDS, perception, and education, while the dependent variable was negative stigma for people with HIV / AIDS. The instrument of this study is a questionnaire.

Result: The results showed that there was still a high negative stigma for people with HIV / AIDS with $\mathrm{n}=69(83.1 \%)$. There is a weak relationship between knowledge and negative stigma for people with HIV / AIDS with a value of $\mathrm{X}^{2}$ count 4.110, 0.255. There is a weak correlation between perceptions and negative stigma for people with HIV / AIDS with a value of $\mathrm{X}^{2}$ count 7.338, $\varphi$ 0.331. There is a weak relationship between education and a negative stigma for people with HIV / AIDS with a value of X2count 5.551, $\varphi 0.291$.

Conclusion: Researchers suggest to Ranomeeto Primary Health Care to conduct more frequent health education about HIV / AIDS and form village cadres by providing accurate knowledge about HIV / AIDS, for further researchers to add and look for variables that are closely related to negative stigma for people with HIV / AIDS in the community.

Key words: HIV AIDS, Community Stigma, Patients 


\section{INTRODUCTION}

Data from the World Health Organization (WHO) notes that globally there are 36.9 million people in various countries living with HIV and AIDS in 2017. Of the total sufferers, 1.8 million of them are children under 15 years of age. The rest are adults, some 35.1 million sufferers. Recorded the number of deaths was caused by AIDS as many as 940,000 cases worldwide. That figure consists of 830,000 deaths in adulthood and the remaining 110,000 in children. Most people with HIV / AIDS are found in the East and South Africa Region, with a total of 19.6 million sufferers. Furthermore, in second place is the West and Central Africa Region with 6.1 million people living with it (1).

In Indonesia, from 2005 to March 2019, the number of reported HIV cases reached 338,363 people, while the number of AIDS conditions reported since it was first discovered in 1987 to March 2019 reached 115,601 people. From January to March 2019, 11,081 HIV transmissions were reported, while AIDS cases reached 1,536 people (2).

HIV / AIDS is a disease for which no cure has been found. The sufferers are only given drugs to prevent the spread of the virus in the body. Most of those infected with HIV / AIDS are people whose behavior is morally contrary to religious and social norms. Sometimes they get unpleasant treatment from their family and friends / community, such as ridicule, insults or even other attitudes that show a stigma of disliking HIV / AIDS sufferers (3).

AIDS-related stigma is all prejudice, insults and discrimination directed at PLHIV and individuals, groups or communities associated with PLWHA. The stigma against PLWHA hinders the process of socialization and even treatment because it makes them feel isolated and even considered as people who are insulted by their status as ODHA. The stigma that exists in the community regarding HIV and AIDS is a problem in anticipating the widespread transmission of this disease $(4,5)$.

Some of the factors that influence the stigma for HIV / AIDS, namely HIV / AIDS is a life-threatening disease, people are afraid of being infected with HIV, diseases are associated with stigmatized behaviors in society, PLWHA are often considered to be responsible if someone is infected, values morals or religion make people believe that HIV / AIDS is the result of moral violations. Many of these PLHIV later lost their jobs, were isolated from their families and communities, rejected by health services knowing their HIV status. Stigma and discrimination against people living with HIV / AIDS are influenced by several factors such as knowledge, perception, education, gender, age, economic status, exposure to information sources about HIV / AIDS, as well as interactions with PLHIV also affect a person's stigma for PLWHA (6).

According to data from the Health Office, the number of HIV / AIDS cases in Southeast Sulawesi from 2015 to the end of 2018 continued to increase, in 2015 there were 158 people with HIV / AIDS. Then in 2016 it decreased to 123 people, 2017 as many as 120 people and in 2018 it increased again to 183 people (7).

Based on data from the Health Office, from 17 districts / cities in Southeast Sulawesi, the spread of HIV / AIDS in Kendari City in 2018 was in the first position with the most cases of 52 people. Following the city of Bau-Bau with 24 people and Wakatobi as many as 16 people South Konawe District, especially Ranomeeto District, has a total of 5 people with HIV / AIDS. The village of Boro-Boro is a village located in Ranomeeto District which has 1 person, the number of HIV / AIDS sufferers because the patient works as a female sex worker (FSW), this patient has been recognized by the community (8).

The results of the interviews I had with 7 people in the community stated that they had negative thoughts (negative stigma) towards people with HIV / AIDS, 3 of them 
because of their low knowledge factor, they said that they did not understand and did not get enough information about HIV / AIDS. AIDS, 2 of them because of the perception factor, they said that they had a bad view of PLWHA due to a lack of understanding of HIV / AIDS, and 2 of them because of educational factors, they said that their level of education was still low so they did not get information about HIV / AIDS, this will give a negative stigma to PLWHA due to a lack of knowledge.

\section{METHOD}

This research is a quantitative study with a cross sectional study approach. Respondents in this study were the people of
Boro-Boro Village, Ranomeeto District, South Konawe Regency who were more than 18 years old. The number of respondents was 83 respondents from a population of 585 people. The sampling technique in this study was carried out using accidental sampling. This research is located in Boro-Boro Village, Ranomeeto District, South Konawe Regency from June to July 2020

\section{RESULT}

The Relationship between Knowledge and Negative Stigma for HIV / AIDS Patients in Boro-Boro Village, Ranomeeto District, South Konawe Regency in 2020 as shown in the following table

Table 1. The Relationship between Knowledge and Negative Stigma for HIV / AIDS Patients in Boro-Boro Village, Ranomeeto District, South Konawe Regency in 202

\begin{tabular}{|c|c|c|c|c|c|c|c|}
\hline \multirow{3}{*}{ Knowledge } & \multicolumn{4}{|c|}{ Stigma } & \multicolumn{2}{|c|}{ Total } & \multirow[t]{2}{*}{ Statistic } \\
\hline & \multicolumn{2}{|c|}{ Negatif } & \multicolumn{2}{|c|}{ Positif } & & & \\
\hline & $\mathrm{n}$ & $\%$ & $\mathrm{n}$ & $\%$ & $\mathbf{n}$ & $\%$ & $X_{\text {test }}^{2}=4,110$ \\
\hline Less & 43 & 91.5 & 4 & 8,5 & 47 & 100 & \\
\hline Well & 26 & 72,2 & 10 & 27,8 & 36 & 100 & $\mathrm{X}_{\text {tab }}^{2}=3,841$ \\
\hline Total & 69 & 83,1 & 14 & 16,9 & 83 & 100 & $\varphi=0,255$ \\
\hline
\end{tabular}

The results showed that of the 83 respondents, there were $47 \quad(56.6 \%)$ respondents who had less knowledge, it was found that respondents gave a negative stigma for HIV / AIDS sufferers by 43 $(51.8 \%)$ respondents and those with less knowledge were found respondents gave a positive stigma against people with HIV / AIDS by $4(4.8 \%)$ respondents, while 36 (43.4\%) respondents with good knowledge were found respondents who gave a negative stigma for HIV / AIDS sufferers by 26 (31.3\%) and those with good knowledge were found 10 respondents $(12.0 \%)$ gave a positive stigma for HIV / AIDS sufferers.

Based on the results of the chi-square test for the relationship between knowledge and stigma for people with HIV / AIDS, it shows that $\mathrm{X} 2$ count $(4,110) \geq \mathrm{X} 2$ table $(3,841)$, the research hypothesis $\mathrm{HO}$ is rejected and $\mathrm{Ha}$ is accepted, which means that there is a negative relationship between knowledge and stigma for HIV / AIDS sufferers. in Boro-Boro Village, Ranomeeto District, South Konawe Regency. 
The results of the analysis showed that the value of the phi coefficient was 0.255 and entered the coefficient interval from 0.20 to 0.399 in the weak category. This shows the relationship between knowledge and negative stigma for HIV / AIDS sufferers in
Boro-Boro Village, Ranomeeto District, South Konawe Regency in 2020.

The Relationship between Perceptions and Negative Stigma for HIV / AIDS Patients in Boro-Boro Village, Ranomeeto District, South Konawe Regency in 2020 as shown in the table below:

Table 2. The Relationship between Perceptions and Negative Stigma for HIV / AIDS Patients in Boro-Boro Village, Ranomeeto District, South Konawe Regency in 2020

\begin{tabular}{|c|c|c|c|c|c|c|c|}
\hline \multirow{3}{*}{ Perception } & \multicolumn{4}{|c|}{ Stigma } & \multicolumn{2}{|c|}{ Total } & \multirow[t]{2}{*}{ Statistic } \\
\hline & \multicolumn{2}{|c|}{ Negatif } & \multicolumn{2}{|c|}{ Positif } & & & \\
\hline & $\mathbf{n}$ & $\%$ & $\mathbf{n}$ & $\%$ & $\mathbf{n}$ & $\%$ & $\mathrm{X}_{\text {hit }}^{2}=7,338$ \\
\hline Negatif & 49 & 92,5 & 4 & 7,5 & 53 & 100 & \\
\hline Positif & 20 & 66,7 & 10 & 33,3 & 30 & 100 & $X_{\text {tab }}=3,841$ \\
\hline Total & 69 & 83,1 & 14 & 16,9 & 83 & 100 & \\
\hline
\end{tabular}

The results showed that of the 83 respondents, there were 53 (63.9\%) respondents who had negative perceptions, it was foaund that the respondents gave a negative stigma for HIV / AIDS sufferers by $49(59.0 \%)$ respondents and those who had negative perceptions were found to give positive stigma for people with HIV / AIDS. HIV / AIDS sufferers were $4(4.8 \%)$ respondents, while of the $30 \quad(36.1 \%)$ respondents who had positive perceptions it was found that $20(24.1 \%)$ respondents gave a negative stigma to HIV / AIDS sufferers and those who $10(12.0 \%)$ respondents found positive perceptions who gave a positive stigma to HIV / AIDS sufferers.

Based on the results of the chi-square test for the relationship between knowledge and stigma for people with HIV / AIDS, it shows that $\mathrm{X} 2$ count $(7,338) \geq \mathrm{X} 2$ table
$(3,841)$, the research hypothesis $\mathrm{HO}$ is rejected and $\mathrm{Ha}$ is accepted, which means that there is a perception relationship with negative stigma for HIV / AIDS sufferers. in Boro-Boro Village, Ranomeeto District, South Konawe Regency.

The results of the analysis obtained the value of the coefficient phi of 0.331 and entered the coefficient interval from 0.20 to 0.399 in the weak category. This shows the relationship between knowledge and negative stigma for HIV / AIDS sufferers in Boro-Boro Village, Ranomeeto District, South Konawe Regency in 2020

The Relationship between Education and Negative Stigma for HIV / AIDS Patients in Boro-Boro Village, Ranomeeto District, South Konawe Regency in 2020. As shown in the table below: 


\section{Table 3. The Relationship between Education and Negative Stigma for HIV / AIDS Patients in Boro-Boro Village, Ranomeeto District, South Konawe Regency in 2020}

\begin{tabular}{|c|c|c|c|c|c|c|c|}
\hline \multirow{3}{*}{ Education } & \multicolumn{4}{|c|}{ Stigma } & \multicolumn{2}{|c|}{ Total } & \multirow[t]{2}{*}{ Statistic } \\
\hline & \multicolumn{2}{|c|}{ Negatif } & \multicolumn{2}{|c|}{ Positif } & & & \\
\hline & $\mathbf{n}$ & $\%$ & $\mathbf{n}$ & $\%$ & $\mathrm{n}$ & $\%$ & $X_{\text {test }}^{2}=5,551$ \\
\hline High & 46 & 92,0 & 4 & 8,0 & 50 & 100 & $X_{\text {tab }}^{2}=3,841$ \\
\hline Low & 23 & 69.7 & 10 & 30,3 & 33 & 100 & $\varphi=0,291$ \\
\hline Total & 69 & 83,1 & 14 & 16,9 & 83 & 100 & \\
\hline
\end{tabular}

The results showed that of the 83 respondents there were $50 \quad(60.2 \%)$ respondents with low education, it was found that respondents gave a negative stigma for HIV / AIDS sufferers by 46 (55.4\%) respondents and those with low seeducation were found respondents gave a positive stigma against HIV / AIDS sufferers. / AIDS by $4(4.8 \%)$ respondents, while from 33 (39.8\%) respondents who had a high education, it was found that $23(27.7 \%)$ respondents gave a negative stigma to HIV / AIDS sufferers and those with high education It was found that 10 respondents gave a positive stigma against HIV / AIDS sufferers $(12.0 \%)$.

Based on the results of the chi-square test for the relationship between education and stigma against people with HIV / AIDS, it shows that $\mathrm{X} 2$ count $(5,551) \geq \mathrm{X} 2$ table $(3,841)$, the research hypothesis $\mathrm{H} 0$ is rejected and $\mathrm{Ha}$ is accepted, which means that there is a negative relationship between education and stigma against HIV / AIDS sufferers. in Boro-Boro Village, Ranomeeto District, South Konawe Regency. The results of the analysis showed that the value of the phi coefficient was 0.291 and entered the coefficient interval from 0.20 to 0.399 in the weak category. This shows the relationship between education and negative stigma against HIV / AIDS sufferers in Boro-Boro Village, Ranomeeto District, South Konawe Regency in 2020

\section{DISCUSSION}

Since it was first discovered, HIV /AIDS has caused various responses such as rejection, fear, stigma and discrimination which have caused anxiety and prejudice against people with HIV / AIDS. Stigma is the act of giving a social label that aims to separate or discredit a person or group of people with bad labels or views. In practice, stigma results in acts of discrimination, namely the act of not recognizing or failing to fulfill the basic rights of individuals or groups as should be human beings with dignity (4).

Lack of knowledge about HIV / AIDS tends to give a negative stigma against people with HIV / AIDS. Stigma and discrimination against HIV / AIDS sufferers are influenced by the level of knowledge, this is in accordance with the results of research in Kupang City, NTT Province which states that respondents who have less knowledge give a high stigma of $75 \%$ and low stigma amounted to $24.7 \%$, while respondents who have good knowledge give a high stigma of $33.9 \%$ and a low stigma of $66.1 \%$ in this study there is a significant relationship between knowledge and stigma in PLWHA (9).

According to Febrianti's research (2017) respondents who have less knowledge have a heavy stigma of $76.4 \%$ and a mild stigma of $23.6 \%$, while respondents who 
have good knowledge give a heavy stigma of $54.7 \%$ and a mild stigma of $45.3 \%$ of this research found that knowledge is related to cause and effect with stigma against PLWHA (6)

This research is also in line with research in Dewantara District, North Aceh Regency, which states that there is a relationship between knowledge and discrimination against PLWHA. In this study, the lower the public's knowledge about HIV / AIDS, the higher the nationalism and PLWHA (10).

Knowledge of HIV / AIDS greatly influences a person's attitude towards people with HIV / AIDS. The stigma against HIV / AIDS sufferers appears related to a person's ignorance of HIV transmission and negative attitudes towards being informed by the HIV / AIDS epidemic, misunderstanding or lack of public knowledge about HIV / AIDS often has an impact on the fear of people living with HIV / AIDS, so that postponement of prevention of HIV / AIDS sufferers.

Lack of correct information about HIV / AIDS and its transmission is caused by talking about matters related to sexual relations which causes obstacles for young people to protect themselves from behaviors that are at high risk of carrying out HIV transmission.

This knowledge of HIV / AIDS causes the public to draw conclusions that are inconsistent with the real knowledge about HIV / AIDS. There are several misconceptions about HIV / AIDS, such as HIV / AIDS can be transmitted through social contact such as shaking hands, eating together, breathing air around PLHIV, and others. This misconception has led to stigmatization of HIV / AIDS sufferers.

Perception is the process of observing the outside world which includes attention to understanding and recognition of objects or events (11). The strength of the general public's view of HIV / AIDS, which is a sexually transmitted disease and has a stigma in Indonesian culture. Those who contract this disease are considered dirty, immoral and sinful. This negative assessment causes sufferers to be embarrassed to go for treatment so that they tend to hide their disease, so that it will endanger the wider community.

Respondents with negative perceptions tend to give negative stigma to people with HIV / AIDS. The perception of people living with HIV or people with AIDS will greatly affect how that person will behave and behave towards people with HIV / AIDS.

This research is in accordance with the study of concerning Community Stigma Against People With HIV / AIDS which shows that someone who has negative perceptions of PLWHA has a twice as large risk of committing stigma than with people who have positive perceptions. This stigma arises because the public does not know correct and complete information on HIV, especially about the mechanism of HIV transmission, groups of people at risk of contracting HIV and ways of prevention, including the use of condoms (12).

This research is also in line with research in Kupang City, NTT Province, it was found that $70 \%$ of respondents who had a lack of perception gave high stigma to PLWHA. Meanwhile, respondents who had a good perception gave a high stigma against PLWHA, 26.4\%. In this study, there is a significant relationship between knowledge and stigma in PLWHA (9).

In social life, stigma also prevents PLWHA from carrying out social activities. PLWHA is closed off and tends not to be willing to interact with family, friends and neighbors. This is because some people think that people who are HIV positive are people who have bad behavior such as female sex workers, drug users, and homosexuals. This group is considered by some people to influence the HIV / AIDS epidemic and make people reject and hate the group.

Education is all efforts that are planned to influence other people so that they do what is expected by education (13). Education is an individual learning process 
in order to have an understanding and knowledge of something.

The research is in line with research in Dewantara District, North Aceh Regency, which states that there is a relationship between education and discrimination against PLHIV. It can be explained that the lower the level of education, the discrimination against PLHIV will also be higher. In population groups with high education, it can reduce discrimination against PLWHA, with higher education someone will get enough information about PLWHA so that it affects attitudes towards PLWHA (10).

High education also makes it easier for someone to access health information. The ease with which a person absorbs information will influence the formation of new, healthier behaviors, such as health information about HIV / AIDS (10).

A person's education greatly affects a person's attitude towards people with HIV / AIDS. The stigma against people with HIV / AIDS appears related to a person's ignorance of the mechanism of HIV transmission due to a person's low education, which results in a misunderstanding or a lack of public knowledge about HIV / AIDS.

Low education causes the community to have conclusions that are inconsistent with real knowledge of HIV / AIDS. There are several misconceptions about HIV / AIDS, such as HIV / AIDS can be transmitted through social contact such as shaking hands, eating together, breathing air around PLHIV, and others. This misconception has led to stigmatization of HIV / AIDS sufferers.

One of the obstacles in controlling HIV / AIDS is the existence of stigma and discrimination against HIV / AIDS sufferers, the provision of information related to HIV / AIDS through health education and socialization is very effective in reducing the stigma of society towards PLWHA. Someone with high education and understanding related to HIV / AIDS is expected to reduce and even eliminate the stigma in PLWHA.

\section{CONCLUSION}

e- ISSN: 2715-4718

Based on the research results it can be concluded as follows:

1. There is a weak relationship between Knowledge and a negative stigma against people with HIV / AIDS in Boro-Boro Village, Ranomeeto District, South Konawe District.

2. There is a weak relationship between Perception and negative stigma against HIV / AIDS sufferers in Boro-Boro Village, Ranomeeto District, South Konawe District.

3. There is a weak relationship between education and a negative stigma against people with HIV / AIDS in Boro-Boro Village, Ranomeeto District, South Konawe District

\section{REFERENCES}

1. UNAIDS, 2017. HIV / AIDS in Figures: 36.9 Million Sufferers, 25 Percent Unaware. [on line]. (updated December 1, 2018). Accessedd https://amp.kompas.com/lifestyle/read/ 2018/12/01/124545720/hivaids-dalamangka-369-juta-penderita-25-persentak-menyadarinya 2nd February 2020. (Indonesia)

2. Rahmawati, M., 2019. Combating HIV / AIDS in Indonesia under the RKUHP Threat. South Jakarta: Institute for Criminal Justice Reform (ICJR). (Indonesia)

3. Hermawati, P., 2011. The Relationship between Perceptions of PLWHA and the Stigma of HIV / AIDS in the Community and Social Interactions of PLWHA. Undergraduate thesis. Faculty of Psychology. Syarif Hidayatullah State Islamic University Jakarta, Jakarta. (Accessed 30th Januari 2020). (Indonesia)

4. Firman, 2017. HIV/AIDS Nursing Care. Kendari: CV. Metro Graphia Kendari. (Indonesia)

5. Tjay Tan Hoan \& Rahardja Kirana. 2008. Important Drugs Efficacy, Use, 
and Side Effects. Jakarta: Pt Elex Media Komputindo. (Indonesia)

6. Febrianti, 2017. Factors Related to Stigma for People Living with HIV and AIDS (PLWHA). Journal Endurance, 2 (2), hal. 158-167. (accessed 28th Januari 2020). (Indonesia)

7. Provincial govermnet Southeast Sulawesi, 2019. HIV / AIDS cases in Southeast Sulawesi reached 183 people. [on line]. (updated April 23, 2019).

https://www.google.com/amp/s/penasu ltra.com/amp/kasus-hiv-aids-di-sultracapai-183-orang/ (Accessed 2nd Februari 2020). (Indonesia)

8. Health Profile Provincial govermnet Southeast Sulawesi 2017. Data \& Information of Southeast Sulawesi Provincial Health Office. Kendari. (Accessedd at www.dinkes.sultraprov.go.id 2nd Februari 2020). (Indonesia).

9. Konstantinus, H., Zahroh, S., \& Antono, S., 2017. Community Sitgma for PLWHA in Kupang City, NTT Province. Jurnal of Health Promotion Indonesia, 1 (12), page 62-77. (Accessed 2nd Februari 2020). (Indonesia).

10. Nurma, Fahmi, I., Syarifuddin, A., \& Nelly, M., 2018. The Cause of Discrimination in Dewantara Subdistrict, Aceh Utara District for People with HIV-AIDS. Health Research Journal , 1 (5), page. 1-9. (Accessed 1st Februari 2020). (Indonesia).

11. Sunaryo, 2004. Psychology For Nursing. Jakarta: EGC. (Indonesia)

12. Kasanah, U., \& Lintang, K., F., I., 2017. The Relationship between Public Perceptions of HIV and Discriminatory Stigma Incidents in PLWHA (People With HIV / AIDS) in Pati District, 2017. (Journal of Midwifery Science and Health), 2 (9), page. 124-134. (Accessed 27th Januari 2020). (Indonesia).
13. Maulana, D., J., Heri, 2009. Health Promotion. Jakarta: EGC. (Indonesia) 